\title{
Wood Cross-arms Coated with Polyurethane Resin - Tests and Numerical Simulations
}

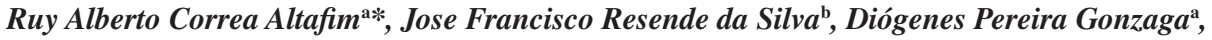 \\ Cacilda Ribeiro $^{\mathrm{c}}$,João Godoy, Heitor Curry Basso ${ }^{\mathrm{a}}$, Benedito Bueno ${ }^{\text {a }}$, Carlito Calil Júnior , \\ Jose Carlos Sartori, Ruy Alberto Pisani Altafim ${ }^{\mathrm{a}}$, Alex Silveira ${ }^{\mathrm{b}}$ \\ ${ }^{a}$ São Carlos School of Engineering, University of São Paulo, \\ C. P. 359, 13566-590 São Carlos - SP, Brazil \\ ${ }^{\mathrm{b}}$ Power Utility, Elektro S. A., Campinas - SP, Brazil \\ ${ }^{\mathrm{S} S c h o o l}$ of Electrical and Computer Engineering, Federal University of Goiás, GO, Brazil
}

Received: December 2, 2004; Revised: October 11, 2005

\begin{abstract}
Brazil's electric power utilities have commonly employed native timbers as the main material for manufacturing cross-arms for distribution lines. However, the increasingly high costs of these timbers and Brazil's new environmental laws have contributed to change this situation, spurring research on new materials for application in transmission and distribution systems. This paper discusses two reforested wood species, Pinus elliottii and Eucalyptus citriodora, coated with castor oil-based polyurethane resins, as an alternative material for distribution line cross-arms, from the standpoint of their mechanical and electrical properties and their low cost. Numerical simulations and a complete description of the entire coating process are also part of this work.
\end{abstract}

Keywords: wood cross-arm, polymers, electrical and mechanical tests, computer simulations

\section{Introduction}

The increasingly high cost of native wood and new environmental laws have contributed to the emergence of alternative materials for the production of mechanical supports for transmission and distribution lines ${ }^{1}$. Norway, for example, has been using laminated woods for over twenty years, first for cross-arms in distribution lines and later for completes 66 and $134 \mathrm{kV}$ transmission line structures ${ }^{2}$. In the early $1990 \mathrm{~s}$, in the US, Union Electric (U.E) also evaluated alternatives for solid wood products, whose prices have increased steadily over the last decade, particularly those of cross-arms. U.E has found that laminated wood cross-arms can offer an economically feasible alternative at a cost equal to or lower than solid sawn cross-arms ${ }^{3}$. In this context, although laminated wood is an alternative material for Brazil, reforested Pinus elliottii and Eucalyptus citriodora, which satisfy the strength, electrical and thermal requirements for solid sawn crossarms $^{4}$, are also economically viable, provided they receive special protective surface treatment against fungi and microorganisms.

This paper presents and discusses reforested Pinus elliottii and Eucalyptus citriodora cross-arms coated with a castor oil-based polyurethane resin - Ricinus communis ${ }^{5-7}$. The first part of this work consisted of countless computer simulations to establish limits for mechanical testing. These tests, combined with electrical tests, confirmed that this new surface treatment increases the lifetime of cross-arms under environmental conditions. The mechanical and electrical properties of these polyurethane-coated cross-arms were also analyzed, proving that the product is market competitive and ecologically acceptable.

\section{Numerical Computer Simulation}

To define equipments, limits and parameters of mechanical tests, described on topic 3.5, simulations of the mechanical behavior of for reforested wood cross-arms were carried out using the ANSYS $6.1^{\circledR}$ software program based on the finite element method (FEM) In this context, to reduce the processing time in these simulations, the thin layer of polyurethane resins was not included; instead, a mesh containing 3,890 elements was employed. Table 2 shows some simulations and the experimental results.

In the preprocessing phase, a Brazilian-NBR-8458 standard cross-arm ${ }^{9}$, illustrated in Figure 1, was drawn using the solid generation system, after which the aforementioned software generated the meshes. The contour conditions for the bending test (see Figure 4) were introduced in a subsequent step. The processing was executed in static regime, using a model without holes and with sharp edges. Figure 2 shows a simulation in which $5.49 \mathrm{kN}(560 \mathrm{kgf})^{9}$ was applied on the points indicated.

\section{Experimental Methods and Procedures}

\subsection{Samples}

The samples used in this research were made of the reforested species Eucalyptus citriodora and Pinus elliottii, whose average elasticity modulus and strength values are listed in Table 1, which also shows other native woods used for cross-arms ${ }^{4}$.

\subsection{Resin coating process}

All the wood destined for testing was dried at room temperature and coated with resin without filler. The resin, dubbed RI 3, was prepared by weighing the polyol on a semi-analytic scale, to which the pre-polymer was added in a mass proportion of $1: 1.5$. These two components were mixed for about 3 min in a vacuum below $100 \mathrm{mbar}$ to extract air bubbles. A homogeneous $0.2 \mathrm{~mm}$ thick layer of resin was 

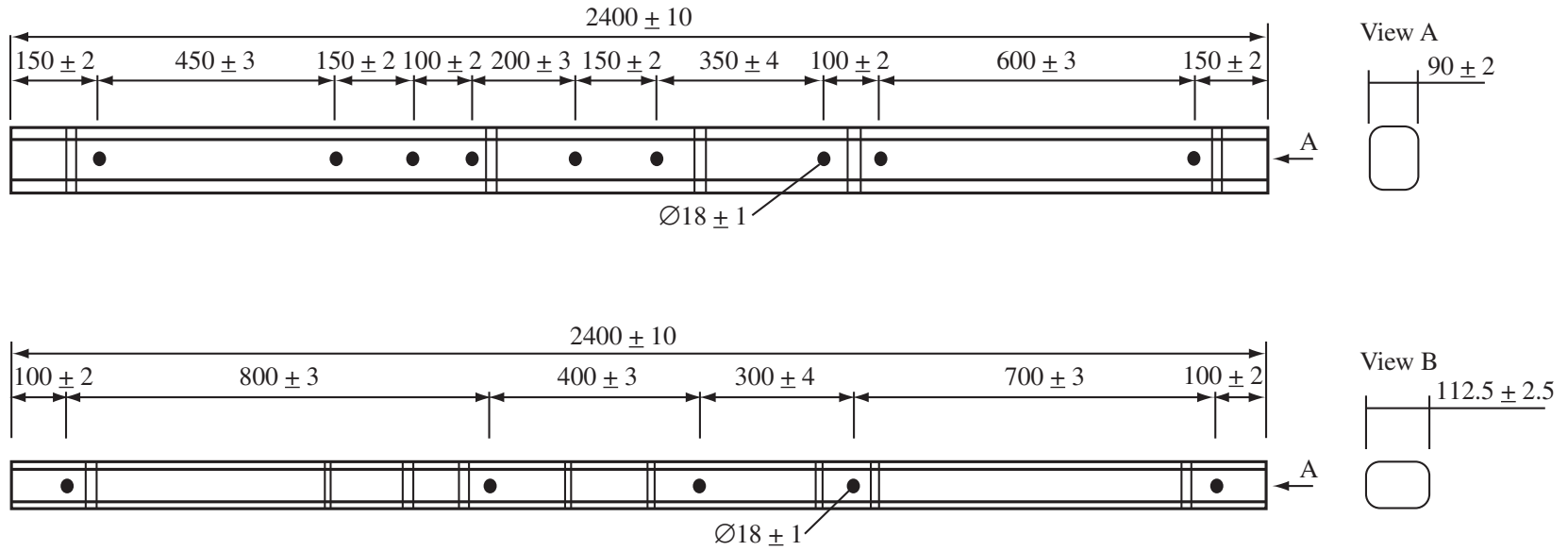

Figure 1. Wooden cross-arm with standards holes and 2.4 meter long.

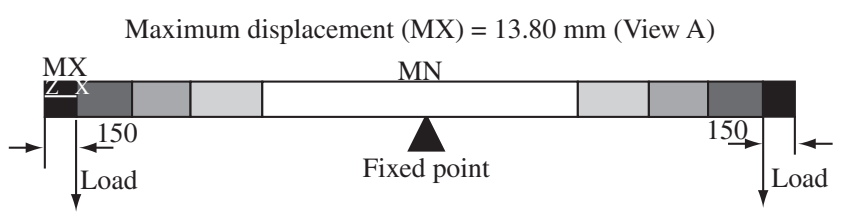

Figure 2. Example of ANSYS cross-arm simulation, in which a force of $5.49 \mathrm{kN}$ (560 kgf) was applied at the two points indicated (View A).

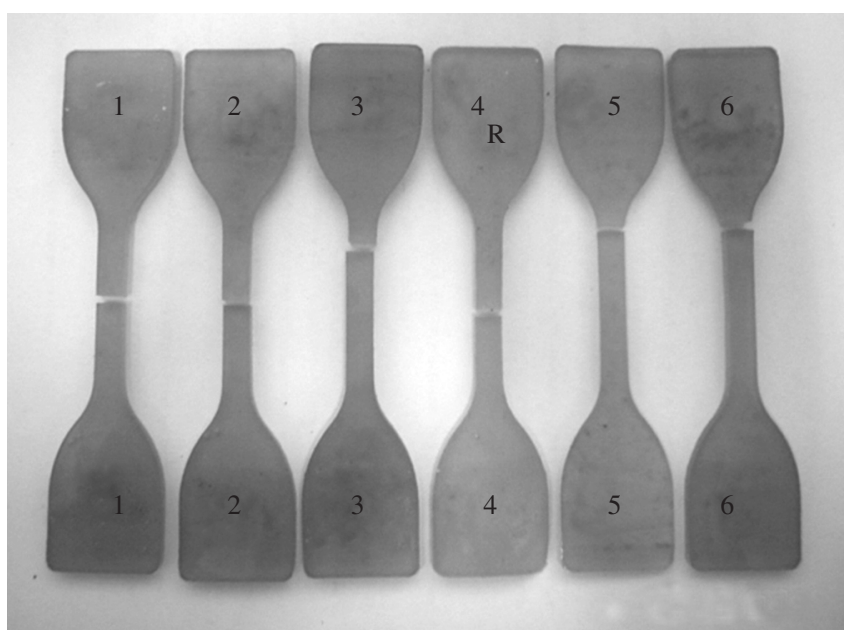

Figure 3. Samples used to determine the resin's elasticity modulus.

Table 1. Average values of elasticity modulus and strength ${ }^{4}$.

\begin{tabular}{lccc}
\hline Wood & $\rho_{\mathrm{ap}}{ }^{(1)} \mathrm{kg} / \mathrm{m}^{3}$ & $\mathrm{E}_{\mathrm{CO}}{ }^{(2)} \mathrm{MPa}$ & $\mathrm{f}_{\text {to }}^{\left({ }^{(3)}\right.} \mathrm{MPa}$ \\
\hline Eucalyptus citriodora & 999 & 18,421 & 123.6 \\
Pinus elliottii & 560 & 11,889 & 66.0 \\
Hymenaea spp & 1,074 & 23,607 & 157.5 \\
Bagassa guianensis & 940 & 19,583 & 78.8 \\
Tabebuia serratifolia & 1,068 & 18,011 & 96.8 \\
\hline
\end{tabular}

(1) $\rho_{\text {ap }}=$ apparent specific mass at $12 \%$ of humidity

(2) $\mathrm{E}_{\mathrm{CO}}=$ elasticity modulus

(3) $\mathrm{f}_{\text {to }}=$ paralel fiber tensile strength applied with a brush or a piece of cotton on the wood surface under environmental conditions of $25^{\circ} \mathrm{C}$ and a relative humidity of $50 \%$.

\subsection{Young's modulus of elasticity of the resin}

Five 3-mm thick samples of RI 3 were allowed to cure for 120 hours, after which they were subjected to tensile mechanical tests, in accordance with the ASTM D638 standard ${ }^{10}$. For these tests, which yield the resin's Young's modulus and the maximum strength, a universal EMIC testing machine at a maximum capacity of $30 \mathrm{kN}$ and a speed of $50 \mathrm{~mm} / \mathrm{min}$ was used. Figure 3 depicts an example of the samples.

\subsection{Shear tests}

To verify the adherence of resin on the wood, five samples prepared according to ASTM D6392-99 specifications ${ }^{11}$ were subjected to a shear test 24 hours after the gluing process. Each sample consisted of two rectangular pieces of wood with dimensions of $2 \times 15 \mathrm{~cm}$, glued along one of their edges with RI3 resin. The gluing area was $600 \mathrm{~mm}^{2}$ and $0.2 \mathrm{~mm}$ thick. The tests were carried out in an EMIC ${ }^{\circledR}$ universal testing machine at a maximum capacity of $100 \mathrm{kN}$ and a speed of $5.0 \mathrm{~mm} / \mathrm{min}$.

\subsection{Mechanical tests}

Twenty cross arm prototypes for the mechanical tests were prepared on a full scale with dimensions of $90 \times 112.5 \times 2,400 \mathrm{~mm}$ and with standards holes, as illustrated by the diagram in Figure 1. These tests involved impregnated and non-impregnated wood. To identify the different samples during these tests, they were given the same codes as those of the electrical tests.

The bending strength properties were measured based on the ABNT standard ${ }^{9}$, using a VICKERS ${ }^{\circledR-}$ model XG 06 F 20 hydraulic machine, a Mitutoyo ${ }^{\circledR}$ comparative mechanical transducer - model BBY 051, $\mathrm{N}^{\circ} .3058 \mathrm{~F}$ and a Templec ${ }^{\circledR}$ humidity and temperature meter. The tests were conducted at a temperature of $21^{\circ} \mathrm{C}$ and relative air humidity of $61 \%$.

Figure 4 shows a detail of force application point and fixed point of these tests.

\subsection{Electrical tests}

The electrical tests for surface resistivity, $\rho_{s}$, and dielectric dissipation factor, $\tan \delta$, were carried out on $50 \times 120 \times 6 \mathrm{~mm}$ resincoated samples of Eucalyptus citriodora impregnated with oil (CT), 
non-impregnated Eucalyptus citriodora $(\mathrm{CN})$, and non-impregnated Pinus elliottii (PN). These tests, each of which involved five samples, were conducted according to the ASTM standard ${ }^{12-14}$.

Similarly prepared samples were used to evaluate the resistance to tracking and erosion under severe ambient conditions. Ammonium chloride $(0.1 \%)$ with Antrox $(0.002 \%)$, with a conductivity of $2.53 \mathrm{mS} / \mathrm{cm}$, was used as a contaminating solution. In preparation for this test, five samples were sandpapered and cleaned with isopropyl alcohol. The test operator defined the initial test voltage, which was increased in increments of $250 \mathrm{~V}$ per hour until the end of the test, determined by the electrical rupture of several samples.

\section{Results}

\subsection{Simulation and experimental results}

Tables 2 and 3 show some computational simulations and list the mean values of the mechanical bending tests.

\subsection{Experimental results}

The results of the mechanical tensile tests to determine the resin's modulus of elasticity and the tensile strength are shown in Table 4.
Tables 5, 6 and 7 give the shear test results for resin impregnated and non-impregnated Eucalyptus citriodora and Pinus elliottii, glued with RI 3 resin with a cure time of 48 hours and glued area of $600 \mathrm{~mm}^{2}$.

As shown in Tables 5, 6 and 7, the polyurethane resin adhered very well to the wood, withstanding an average shearing strength of

Table 4. Results of mechanical tensile tests of Resin RI 3 cured for 120 hours.

\begin{tabular}{lrrrc}
\hline $\begin{array}{c}\text { Sample } \\
\text { identification }\end{array}$ & $\begin{array}{c}\text { Maximum } \\
\text { strength } \\
(\mathrm{MPa})\end{array}$ & $\begin{array}{c}\text { Specific } \\
\text { strain of } \\
\text { the device } \\
(\%)\end{array}$ & $\begin{array}{c}\text { Tensile } \\
\text { stress } \\
(\mathrm{MPa})\end{array}$ & $\begin{array}{c}\text { Young's modulus } \\
\text { of elasticity } \\
(\mathrm{Gpa})\end{array}$ \\
\hline 1 & 97.1 & 117.1 & 5.092 & 10.00 \\
2 & 108.9 & 135.7 & 7.842 & 12.73 \\
3 & 109.3 & 126.5 & 6.946 & 18.00 \\
4 & 109.2 & 129.9 & 7.042 & 14.27 \\
\hline Average value & 106.1 & 127.3 & 6.730 & 13.75 \\
Standard & 5.6 & 6.1 & 17.29 & 24.27 \\
deviation $(\%)$ & & & & \\
\hline
\end{tabular}

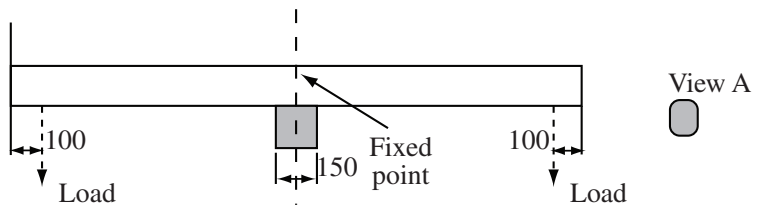

(a)

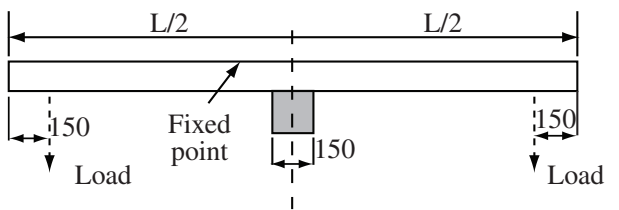

(b)

Figure 4. Detail of the bending test: a) View A; and b) View B.

\begin{tabular}{llccc}
\cline { 2 - 4 } & $\begin{array}{c}\text { Sample } \\
\text { identification }\end{array}$ & $\begin{array}{c}\text { Strength } \\
(\mathrm{MPa})\end{array}$ & $\begin{array}{c}\text { Specific strain } \\
\text { of the device } \\
(\%)\end{array}$ & $\begin{array}{c}\text { Strength/Width } \\
(\mathrm{N} / \mathrm{m})\end{array}$ \\
\cline { 2 - 5 } & 1 & 3.012 & 0.5481 & 125.5 \\
View B & 3 & 2.765 & 0.7041 & 120.2 \\
$\square$ & 4 & 3.917 & 1.238 & 170.3 \\
& 5 & 3.651 & 1.311 & 158.7 \\
& 5 & 2.893 & 0.9469 & 125.8 \\
\hline & Average value & 3.248 & 0.9497 & 140.1 \\
& Standard & 15.59 & 34.74 & 16.2 \\
& deviation $(\%)$ & & & \\
\cline { 2 - 5 } & & & &
\end{tabular}

Table 5. Shear test results - resin impregnated Eucalyptus citriodora.

Table 2. Bending test results and simulations for Eucalyptus citriodora cross-arms.

\begin{tabular}{|c|c|c|c|c|}
\hline 2.4 m Cross-arm & $\begin{array}{c}\text { Situation A } \\
3.92 \mathrm{kN} \\
\end{array}$ & $\begin{array}{c}\text { Situation B } \\
3.92 \mathrm{kN} \\
\end{array}$ & $\begin{array}{l}\text { Situation A } \\
5.49 \mathrm{kN} \\
\end{array}$ & $\begin{array}{c}\text { Situation B } \\
5.49 \mathrm{kN} \\
\end{array}$ \\
\hline Measured displacement (mm) & 5.7 & 7.9 & 8.1 & 11.1 \\
\hline $\begin{array}{l}\text { Displacement resulting from } \\
\text { ANSYS simulation (mm) }\end{array}$ & 9.8 & 14.8 & 13.8 & 20.7 \\
\hline $\begin{array}{l}\text { Maximum allowed displacement } \\
\text { from standard NBR } 8458(\mathrm{~mm})\end{array}$ & 11.5 & 11.5 & 16.3 & 16.3 \\
\hline
\end{tabular}

Table 3. Bending test results and simulations for Pinus elliottii.

\begin{tabular}{lcccc}
\hline 2.4 m Cross-arm & $\begin{array}{c}\text { Situation A } \\
3.92 \mathrm{kN}\end{array}$ & $\begin{array}{c}\text { Situation B } \\
3.92 \mathrm{kN}\end{array}$ & $\begin{array}{c}\text { Situation A } \\
5.49 \mathrm{kN}\end{array}$ & $\begin{array}{c}\text { Situation B } \\
5.49 \mathrm{kN}\end{array}$ \\
\hline Measured displacement (mm) & 17.6 & 24.3 & 25.1 & 33.6 \\
$\begin{array}{l}\text { Displacement resulting from ANSYS } \\
\text { simulation (mm) }\end{array}$ & 15.3 & 22.9 & 21.4 & 32.1 \\
$\begin{array}{l}\text { Maximum displacement from standard } \\
\text { NBR 8458 (mm) }\end{array}$ & 11.5 & 11.5 & 16.3 & 16.3 \\
\hline
\end{tabular}


more than $2.40 \mathrm{kN}$ over a glued area of $600 \mathrm{~mm}^{2}$. Another important point was that the impregnation resin presented a shiny surface with only a very slight change in the wood color, which allows harmonizing the structure with the natural surroundings.

The bending test data for $3.92 \mathrm{kN}$ and $5.49 \mathrm{kN}$ listed in Tables 8 and 9, respectively, indicate that oil-impregnated Eucalyptus citriodora displays excellent mechanical bending strength and a displacement value well below the maximum displacement allowed by the NBR-8458 standard ${ }^{9}$. However, although its displacement value was lower than the maximum displacement recommended by the NBR-8458 standard, Pinus elliottii broke during the test at points

Table 6. Shear test results - non-oil impregnated Eucalyptus citriodora.

\begin{tabular}{lccc}
\hline $\begin{array}{c}\text { Sample } \\
\text { identification }\end{array}$ & $\begin{array}{c}\text { Maximum } \\
\text { strength } \\
(\mathrm{kN})\end{array}$ & $\begin{array}{c}\text { Specific strain } \\
\text { of the device } \\
(\%)\end{array}$ & $\begin{array}{c}\text { Strength/Width } \\
(\mathrm{N} / \mathrm{m})\end{array}$ \\
\hline 1 & 2.724 & 0.438 & 110.3 \\
2 & 2.552 & 0.442 & 103.3 \\
3 & 2.245 & 0.557 & 91.6 \\
4 & 1.760 & 0.329 & 74.9 \\
5 & 2.877 & 0.562 & 122.4 \\
\hline Average value & 2.432 & 0.466 & 100.5 \\
Standard & 18.2 & 20.8 & 18.1 \\
deviation $(\%)$ & & & \\
\hline
\end{tabular}

Table 7. Shear test results - Pinus elliottii.

\begin{tabular}{lccc}
\hline $\begin{array}{c}\text { Sample } \\
\text { identification }\end{array}$ & $\begin{array}{c}\text { Maximum } \\
\text { strength } \\
(\mathrm{kN})\end{array}$ & $\begin{array}{c}\text { Specific strain } \\
\text { of the device } \\
(\%)\end{array}$ & $\begin{array}{c}\text { Strength/Width } \\
(\mathrm{N} / \mathrm{m})\end{array}$ \\
\hline 1 & 3.075 & 1.249 & 130.8 \\
2 & 3.194 & 1.018 & 135.9 \\
3 & 2.993 & 1.076 & 127.4 \\
4 & 2.273 & 0.769 & 96.7 \\
5 & 2.712 & 1.415 & 115.4 \\
\hline Average value & 2.849 & 1.105 & 121.2 \\
Standard & 12.9 & 22.1 & 12.9 \\
deviation (\%) & & & \\
\hline
\end{tabular}

Table 8. Load bending test at $3.92 \mathrm{kN}$ (400 kgf).

\begin{tabular}{|c|c|c|c|}
\hline \multirow[t]{2}{*}{2.4 meter Cross-arm } & \multicolumn{2}{|c|}{$\begin{array}{l}\text { Displacement } \\
\text { measured } \\
(\mathrm{mm})\end{array}$} & \multirow[t]{2}{*}{$\begin{array}{l}\text { Maximum displace- } \\
\text { ment allowed by } \\
\text { NBR } 8458(\mathrm{~mm})\end{array}$} \\
\hline & A & B & \\
\hline $\begin{array}{l}\text { Eucalyptus citriodora } \\
\text { Oil-impregnated }\end{array}$ & 5.73 & 7.95 & 11.5 \\
\hline $\begin{array}{l}\text { Eucalyptus citriodora } \\
\text { Oil-impregnated and } \\
\text { polyurethane resin coated }\end{array}$ & 4.79 & 6.21 & 11.5 \\
\hline $\begin{array}{l}\text { Pinus elliottii } \\
\text { in its natural state }\end{array}$ & 17.62 & 24.30 & 11.5 \\
\hline $\begin{array}{l}\text { Pinus elliottii } \\
\text { in its natural state and } \\
\text { polyurethane resin coated }\end{array}$ & 9.12 & 13.25 & 11.5 \\
\hline
\end{tabular}

where the wood contained a knot. Even so, the mechanical bending strength of both these wood species increased further with the application of polyurethane resin coating.

Table 10, which lists the bending strength values, indicates that Eucalyptus citriodora showed an excellent performance, with a bending strength approximately $150 \%$ higher than the minimum bending strength admitted by the ABNT standard. However, although the bending strength of Pinus elliotti I, in its natural state and polyurethane resin coated, was greater than the minimum bending strength recommended by the ABNT standard, due this wood has so many weak points (knots), it will not be recommended for this type of application.

An analysis of the results of the electrical tests shown in Table 11 and of the results reported by reference 6 reveals that, in this impregnation process, the resin's electrical characteristics predominate over the wood's electrical characteristics, indicating the strong influence of the superficial resin layer.

Table 12 shows the electrical rupture voltage and the electrical rupture mode of the test to evaluate tracking and erosion resistance under severe environmental conditions, according to the ASTM D2303 standard.

Table 9. Load bending test at $5.49 \mathrm{kN}$ (560 kgf).

\begin{tabular}{|c|c|c|c|}
\hline \multirow[t]{2}{*}{2.4 meter Cross-arm } & \multicolumn{2}{|c|}{$\begin{array}{l}\text { Displacement } \\
\text { measured } \\
(\mathrm{mm})\end{array}$} & \multirow[t]{2}{*}{$\begin{array}{l}\text { Maximum displacement } \\
\text { allowed by NBR } 8458 \\
(\mathrm{~mm})\end{array}$} \\
\hline & A & B & \\
\hline $\begin{array}{l}\text { Eucalyptus citriodora } \\
\text { Oil-impregnated }\end{array}$ & 8.12 & 11.08 & 16.3 \\
\hline $\begin{array}{l}\text { Eucalyptus citriodora } \\
\text { Oil-impregnated and } \\
\text { polyurethane resin } \\
\text { coated }\end{array}$ & 6.56 & 8.60 & 16.3 \\
\hline $\begin{array}{l}\text { Pinus elliottii* } \\
\text { in its natural state }\end{array}$ & 25.14 & 33.63 & 16.3 \\
\hline $\begin{array}{l}\text { Pinus elliottii* } \\
\text { in its natural state and } \\
\text { polyurethane resin } \\
\text { coated }\end{array}$ & 12.55 & 18.12 & 16.3 \\
\hline
\end{tabular}

*Rupture of the sample occurred during the test.

Table 10. Cross-arm bending strength.

\begin{tabular}{lcc}
\hline Cross-arm made of & $\begin{array}{c}\text { Bending } \\
\text { strength (MPa) }\end{array}$ & $\begin{array}{c}\text { Minimum bending } \\
\text { strength allowed by } \\
\text { the ABNT (MPa) }\end{array}$ \\
\hline $\begin{array}{l}\text { Eucalyptus citriodora } \\
\begin{array}{l}\text { Oil-impregnated } \\
\text { Eucalyptus citriodora }\end{array}\end{array}$ & 20,162 & 7,845 \\
$\begin{array}{l}\text { Oil-impregnated and } \\
\text { polyurethane resin coated }\end{array}$ & 28,123 & 7,845 \\
$\begin{array}{l}\text { Pinus elliottii } \\
\text { in its natural state }\end{array}$ & $13,896^{*}$ & 7,845 \\
$\begin{array}{l}\text { Pinus elliottii } \\
\text { in its natural state and } \\
\text { polyurethane resin coated }\end{array}$ & $10,502^{*}$ & 7,845 \\
\hline
\end{tabular}


Table 11. Electrical characteristics of wood coated with polyurethane resin.

\begin{tabular}{lccc}
\hline $\begin{array}{l}\text { Wood coated with } \\
\text { polyurethane resin }\end{array}$ & $\begin{array}{c}\text { Surface } \\
\text { resistivity } \\
\left(\Omega .10^{15}\right)\end{array}$ & $\begin{array}{c}\text { Dielectric } \\
\text { dissipation } \\
\text { factor }(\tan \delta) \\
\text { for } 1.5 \mathrm{kV}\end{array}$ & $\begin{array}{c}\text { Dielectric } \\
\text { dissipation } \\
\text { factor }(\tan \delta) \\
\text { for } 2.0 \mathrm{kV}\end{array}$ \\
\hline $\begin{array}{l}\text { Eucalyptus citriodora } \\
\text { oil-impregnated }\end{array}$ & 1.2 & 0.032 & 0.03 \\
$\begin{array}{l}\text { Pinus elliottii } \\
\text { in its natural state }\end{array}$ & 1.2 & 0.032 & 0.03 \\
\hline
\end{tabular}

Table 12. Tracking and erosion resistance under severe environmental conditions.

\begin{tabular}{lcl}
\hline $\begin{array}{l}\text { Wood coated with } \\
\text { polyurethane resin }\end{array}$ & Rupture voltage $(\mathrm{kV})$ & Rupture mode \\
\hline $\begin{array}{l}\text { Eucalyptus citriodora } \\
\text { Oil-impregnated }\end{array}$ & 2.0 & $\begin{array}{l}\text { Tracking within } \\
\text { Pinus elliottii }\end{array}$ \\
in its natural state & 2.25 & $\begin{array}{l}\text { Tracking wours } \\
\text { Thin }\end{array}$ \\
\hline
\end{tabular}

\section{Conclusions}

An analysis of Table 1 reveals the excellent mechanical properties of reforested Eucalyptus citriodora compared with native tropical wood species and with reforested Pinus elliottii. These excellent properties were confirmed by cross-arm mechanical tests, which indicated a bending strength for this application approximately three times superior to the minimum established by the ABNT standard. The results of the tests on this wood species coated with resin were even better. Eucalyptus citriodora impregnated with preservative oil showed a 10to 30-year longer lifetime under natural weathering conditions. Since polyurethane resin has good hydrophobic and adherence properties, i.e., it is waterproof, wood coated with this resin will remain dry and, if not in contact with fungi or parasites, its mechanical strength and lifetime can be prolonged for many more years. Aging tests are being initiated to determine the average lifetime of Eucalyptus citriodora cross-arms coated with polyurethane resin.

Although Pinus elliottii coated with resin also passed the mechanical tests, its many weak points concentrated at its knots requires it be selected with special care. These weaknesses may limit its application for cross-arm purposes.

Since these resins keep the wood dry, the electrical resistivity of wood, which normally varies greatly with moisture content, especially below the fiber saturation point, remains stable at values of about $10^{14}$ to $10^{16} \Omega$.m, improving the electrical characteristics of these cross-arms. The resistances to tracking and erosion under severe weathering tests also showed a positive impact on the electrical characteristics of these cross-arms, increasing their Basic Impulse Insulation Level-BIL.

With regard to the computer simulations, it can be concluded that they simplify the preparation for mechanical testing and provide a good approximation of mechanical results. However, simulations of large structures coated with a thin layer of resin may sometimes lead to inaccurate results. To minimize this problem, many more elements are usually required than the number employed here, representing a significant increase in computer memory and processing time. New simulations are ongoing to optimize these two parameters.

To conclude, wood cross-arms coated with polyurethane resin may be an economically and technically viable alternative for electric power distribution systems.

\section{Acknowledgments}

This work was accomplished with the collaboration of the Laboratory of Analytical Chemistry, São Carlos Institute of Chemistry (IQSC-USP), the Institute of Electrical Engineering (IEE) - University of São Paulo (USP), the Wood Structures and Geosciences Laboratories at EESC-USP, COMPANHIA ICOTEMA LTDA, and funded by $\mathrm{CNPq}$, a Brazilian research support foundation and by ELEKTRO-ANEEL, Brazil.

\section{References}

1. Silva JFR. Relatório Técnico sobre vida útil de cruzetas em sistemas de Distribuição de Energia. Campinas, Brasil: Eletricidade e Serviços S.A (ELEKTRO); 2001 (in Portuguese).

2. Asböll E. Laminated wood structures in Norwegian Transmission Lines. Proceedings of the International Conference on Overhead Line Design and Construction: Theory and Practice; 1988 Nov 36-39; 1988.

3. Liebel SA, Mueller RE. Douglas Fir Cross-arms Solid Sawn vs. Laminated Comparison, Transmission and Distribution Conference, Proceedings of the IEEE Power Engineering Society; 1994 Apr 581-586; 1994.

4. BRAZILIAN STANDARD. NBR 7190, August 1997, on Project of Wood Structures.

5. Altafim RAC, Murakami CR, Claro Neto S, Araújo LCR, Chierice GO. The effects of fillers on the service properties of polyurethane resins, Materials Research Magazine. 2003; 2(6):187-191

6. Gonzaga DP, Murakami CR, Chierice GO, Altafim RAC. Electrical characterization of castor oil resins. In: International Symposium on Electrical Insulation (ISEI); 1998 Jun 181-185; Arlington, Virginia, USA; 1998.

7. Claro Neto S. Physical and chemical characterization of castor-oil derived polyurethanes used in bone implants. [PhD. thesis]. São Carlos: University of São Paulo, Brazil; 1997.

8. Sylvester P, Ferrari R. Finite Element for Electrical Engineer ed. Cambridge/UK: Cambridge University Press; 1990

9. BRAZILIAN STANDARD. NBR 8458, August 1990 on Wood Cross-arm for Power Distribution System.

10. AMERICAN SOCIETY FOR TESTING AND MATERIALS. ASTM D638. 1996, Standard Test Method for Tensile Properties of Plastics.

11. AMERICAN SOCIETY FOR TESTING AND MATERIALS. ASTM D6392. 1999, Standard Test Method for Determining the Integrity of Nonreinforced Geomembrane Seams Produced using Thermo-Fusion Methods.

12. AMERICAN SOCIETY FOR TESTING AND MATERIALS. ASTM D149. 1978, Standard Test Methods for Dielectric Breakdown Voltage and Dielectric Strength of Electrical Insulating Materials at Commercial Power Frequencies. (Philadelphia, 1978).

13. AMERICAN SOCIETY FOR TESTING AND MATERIALS. ASTM D150-78. 1978, Standard Test Methods for A-C Loss Characteristics and Permittivity (Dielectric Constant) of Solid Electrical Insulation Materials.

14. AMERICAN SOCIETY FOR TESTING AND MATERIALS. ASTM D257-78. 1978, Standard Test Methods for DC Resistance or Conductance of Insulating Materials. 